$\begin{array}{ll}\text { Research Square } & \begin{array}{l}\text { Preprints are preliminary reports that have not undergone peer review. } \\ \text { They should not be considered conclusive, used to inform clinical practice, } \\ \text { or referenced by the media as validated information. }\end{array}\end{array}$

\title{
Novel cyclic peptides from lethal Amanita species through a genomic approach, and major peptide toxins in the ectomycorrhizal association
}

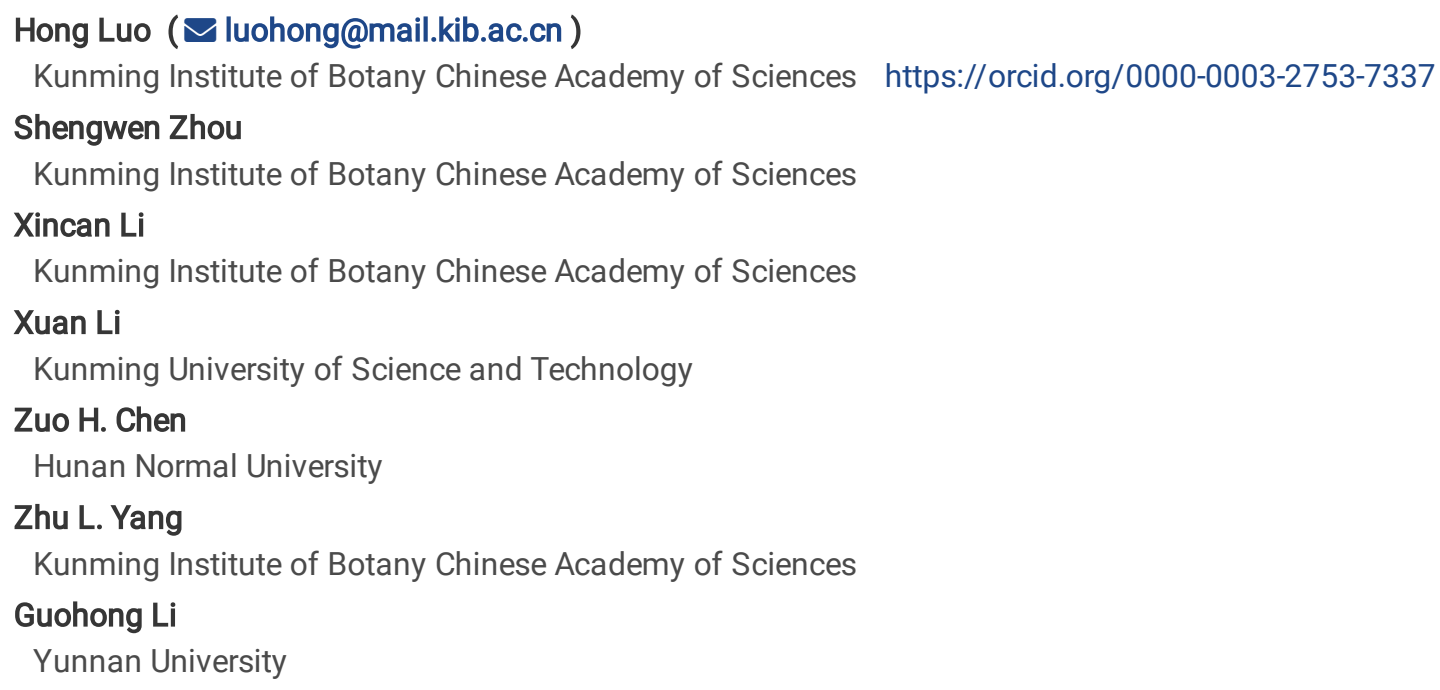

Research

Keywords: Poisonous mushroom, MSDIN family, Amanitin, LC-HRMS

Posted Date: February 18th, 2020

DOl: https://doi.org/10.21203/rs.2.23821/v1

License: @ (i) This work is licensed under a Creative Commons Attribution 4.0 International License. Read Full License 


\section{Abstract}

Background: Most species in the genus Amanita are ectomycorrhizal fungi, and the cyclic peptide toxins that some species produce are notoriously deadly. In total, around 25 of these peptides were found in the fruiting bodies over the past 82 years, and whether any of them are present in the mycorrhizae is unknown. Reportedly, sequenced lethal Amanita genomes harbor a significant number of precursor genes of MSDIN family, indicating there could be a much larger capacity for cyclic peptide production in these mushrooms. However, it is largely unknown that to what extent these genes are transcribed, and further, translated into true cyclic peptides.

Method: In this study, three poisonous Amanita species, $A$. rimosa, A. exitialis and A. subjunquillea, were sequenced through PacBio and Illumina techniques. For expression analysis, one strain of $A$. subjunquillea was sequenced through RNA-Seq. A genome-guided approach was adopted to identify cyclic peptides by coupling predicted toxin-biosynthetic genes with mass spectrometry (MS and MS/MS). To investigate whether any of the toxins were express in the microbiome, profiling of known major toxins was conducted on A. subjunquillea mycorrhizae via HRMS and gene cloning.

Results: The resultant genomes showed significant potential to produce known and unknown cyclic peptides. Together with our 2 previously sequenced genomes, in total 37 unknown MSDIN genes were discovered. Expression of over $90 \%$ of the MSDIN genes was demonstrated in two strains of $A$. subjunquillea. Through the genome-guided approach, 12 MSDIN genes were found to produce true, novel cyclic peptides with no additional posttranslational modifications. When the ectomycorrhizae of $A$. subjunquillea were analyzed by MS, all major toxins were detected. The corresponding MSDINs for these cyclic peptides were successfully cloned directly from the mycorrhizae.

Conclusions: The genome-guided approach provided a speedy method to identify cyclic peptides both in Amanita mushrooms and in the ectomycorrhizae. In this study, a significant number of novel MSDIN genes were discovered, most of which were found to be expressed in the tested species. The identification of the 12 novel cyclic peptides strongly suggests that Amanita species possess a much larger reservoir of these peptides than previously thought. This is the first report to demonstrate that the cyclic peptides in Amanita species are expressed in the mycorrhizal association. All four major toxins, a-amanitin, $\beta$-amanitin, phallacidin and phalloidin, are found to be present in the symbiosis, offering new clues to their biological function(s).

\section{Background}

The genus Amanita (Persoon 1797) is a double-faced twist: on one hand, it harbors some of the best known gourmet mushrooms such as A. caesarea, once favored by emperors of the Roman Empire [1]; on the other, it causes over $90 \%$ of deadly mushroom poisonings worldwide as the collectors have little knowledge of distinguishing the edible from the deadly [2-4]. Majority of the genus are important ectomycorrhizal fungi that have associations with more than ten families of trees [5]; thus, they are important to forest health. So far toxin studies are based on fruiting bodies and, to the best of our knowledge, there is literally no reports on toxins in Amanita mycorrhizae.

Researches on toxins in amanitin-producing (referred as deadly or lethal in this report) Amanita mushrooms date back to the 19th century, but due to technical difficulties in extracting, purifying and analyzing the chemical substances, significant advances were not made until the 20th century [6]. Specifically, Lynen purified one of the major toxins, phalloidin, in 1938 [7]. Then, a-amanitin was purified and crystalized three years later $[8,9]$. The death cap, A. phalloides, became commonly known for its deadly poison in 1951 from death reports [10]. As research progresses, two major types of toxins have been found in dozens of lethal Amanita species, i.e., amatoxins and phallotoxins. The amatoxins function as a highly specific, efficient inhibitor of eukaryotic RNA polymerase II, and the phallotoxins effectively prevent depolymerization of actin fibers [6]. It has been shown that amatoxins and phallotoxins in Amanita are synthesized on ribosomes, which represents the first ribosomal cyclic peptide discovered in Kingdom Fungi [11]. They are encoded by MSDIN gene family as precursor peptides of 34-37 amino acids. The precursors are then cleaved and macrocyclized into 7-10 amino acid cyclic peptides by a specialized prolyl oligopeptidase, POPB $[12,13]$. It is a bifunctional enzyme catalyzing both hydrolysis of peptide bond and transpeptidation. To achieve mature state of the toxins, many of these resultant cyclic peptides need to undergo further posttranslational modifications, mainly including multiple hydroxylations, sulfoxidation, epimerization, and formation of a cross-bridge between Trp and Cys, in which order these reactions occur is unknown. The MSDIN genes encoding amatoxins, such as $\alpha$ - and $\beta$-amanitins, and phallotoxins, such as phallacidin and phalloidin, are readily found in the sequenced genomes of lethal Amanita species [11, 14]. In addition, there are 20 to 30 other unknown MSDIN genes discovered in each of these genomes. In the cases of A. bisporigera and A. phalloides, roughly half of the unknown MSDIN genes are found to be expressed at the transcription level, and the results of mass spectrometry indicate that two of the genes can produce corresponding cyclic peptides [15]. In the past 10 years, only a few novel cyclic peptides have been discovered, including amanexitide in A. exitialis [16], and CyIF and CylE in A. phalloides [15]. In total, roughly 25 cyclic 
peptides are known to human knowledge $[1,17]$. In contrast, newly sequenced genomes of lethal Amanita species show that the MSDIN genes far outnumber the known cyclic peptides, indicating there could be a much larger potential for novel cyclic peptides in these mushrooms. However, it is largely unknown whether these MSDINs translate into true cyclic peptides.

Conventional methods for peptide characterization in Amanita mainly use TLC, HPLC, hydrolysis, and NMR techniques, which in general need significant amount of the subjects examined $[1,6,18,19]$. Suggested by HPLC analyses in many laboratories, the most significant peptide production in Amanita species is attributed to the major toxins, i.e., a-amanita, $\beta$-amanitin, phallacidin and phalloidin [13, 20, 21]. Noticeably, a number of less significant peaks were present in the vicinity of these known peptides, many of which are of insufficient amount for further analyses via conventional methods. In light of this, a more sensitive method would be well appreciated.

Functionally speaking, cyclic peptides produced by Amanita species are more diverse than commonly known, as they are apparently more than toxins. Antamanide, a cyclic decapeptide, protects mice from phalloidin toxicity. Through competition, the molecule effectively inhibits the uptake of phalloidin by OATP1B1 transporter of the liver cells [22]; the same transporter is used by other phallotoxins [23]. Newer finding suggests the peptide is a novel inhibitor of the mitochondrial permeability transition pore [24]. Cycloamanides (CyIA, CylB, CyIC and CyID), antamanide, and their synthetic derivatives display immunosuppressive activity in both in vivo and in vitro assays [2527]. In A. phalloides, researchers suspected that CylE and CyIF are related to cycloamanides due to sequence similarities [6]. These examples have placed many of the cyclic peptides outside the toxin category, indicating that they may have diverse functions in Amanita mushrooms.

In this study, two lethal Amanita species, A. rimosa and A. exitialis, and an independent strain of A. subjunquillea were sequenced and MSDIN genes mined. Together with our two previous sequenced species, A. pallidorosea and A. subjunquillea, five sets of MSDIN genes were analyzed using combined methods. Cyclic peptides were predicted by directly using amino acid sequences in the core regions of the MSDIN genes. Modifications after cyclization, such as hydroxylation, sulfoxidation and cross-bridge formation, were also taken into consideration. Possible molecular formulas with and without further modifications were generated for all candidate peptides. Through high resolution MS, masses matching putative cyclic peptides were mined. Further amino acid composition was elucidated based on $\mathrm{MS} / \mathrm{MS}$ results, which were analyzed manually and via multiple peptide analyzing platforms. Mass spectrometry was also applied to plant root tips associated with $A$. subjunquillea for detection of known cyclic peptide toxins.

\section{Results}

Amanita genomes

Sequencing-quality fruiting bodies of A. exitialis (Ae) and A. rimosa ( $\mathrm{Ar}$ ) were collected in excellent condition and stored in liquid nitrogen (Fig. 1). For Ae, the $\mathrm{N} 50$ of the draft genome was $3 \mathrm{Mb}$ with the genome size of $49 \mathrm{Mb}$ (GC content $=46.6 \%$ ), and the assembly contained 129 contigs. For Ar, the $\mathrm{N} 50$ was $690 \mathrm{~Kb}$ with the genome size at $45 \mathrm{Mb}$ (GC content $=45.99 \%$ ), and the assembly comprised 134 contigs. An independent strain of A. subjunquillea (As), AsYYH, was sequenced for comparison analysis and the genome had the N50 of $830 \mathrm{~Kb}$. The draft size reached $77 \mathrm{Mb}(\mathrm{GC}$ content $=46.57 \%$ ) with the assembly containing 119 contigs. These genomes were only meant for mining MSDIN genes, and therefore further details of the genomes will be discussed elsewhere.

Mining MSDIN sequences for candidate cyclic peptides

With a combination of multiple known MSDINs as queries, the genomes revealed the presence of MSDIN genes in all three sequenced Amanita species, i.e. As (strain AsYYH), Ae, and Ar, yielding 27, 23 and 39 MSDIN genes, respectively (Table 1-3). In total 89 MSDINs were discovered, and 37 were novel. All genomes possessed MSDIN genes coding for at least three major cyclic peptide toxins, namely aamanitin, $\beta$-amanitin and phallacidin. Overall, the precursor genes share similar structures, designated as leader peptide, core peptide and recognition sequence [28]. Based on the newly discovered MSDINs, linear and cyclic peptides with and without further modifications, were predicted. A schematic diagram of the genome-guided approach was illustrated in Fig. 2. 
Table 1

The MSDIN gene family from two independent strains of Amanita subjunquillea

\begin{tabular}{|c|c|c|c|c|}
\hline Leader Peptide & Core Peptide & Recognition Sequence & Monoisotopic Mass & Expressed \\
\hline MSDINATCLP & IWGIGCNP & CVGDEVAALLTRGEALC & 918.3541(a-amanitin) & $\sqrt{ }$ \\
\hline MSDINATRLP & IWGIGCDP & CVGDEVTALLTRGEALC & 919.3382 ( $\beta$-amanitin) & $\sqrt{ }$ \\
\hline MSDINATRLP & IWGIGCDP & CIGDDVTALLTRGEALC & 919.3382 ( $\beta$-amanitin) & $\sqrt{ }$ \\
\hline MSDINATRLP & AWLATCP & CAGDDVNPTLTRGESLC & 788.316 (phalloidin) & $\sqrt{ }$ \\
\hline MSDINATRLP & AWLVDCP & CVGDDINRRVVSAFA-C & 846.3217 (phallacidin) & $\sqrt{ }$ \\
\hline MSDMNATRLP & LIQRPFAP & CVSDDVDFALIRRCALVYAESSV & 922.5461 & $\sqrt{ }$ \\
\hline MSDINTARLP & HFASFIPP & CIGDDIEMVLKRGESLC & 896.4617 & $\sqrt{ }$ \\
\hline MSDINTARLP & TFLPPLFVPP & CVSDDIEMVLTRGESLC & 1108.6394 & $\sqrt{ }$ \\
\hline MSDINATRLP & LNILPFMLPP & CVGDDVNPTLTRGEDLC & 1135.6536 & $\sqrt{ }$ \\
\hline MSDMNATRLP & LIQRPYAP & CVSDDVNSPLTRGESLC & 938.5410 & $\sqrt{ }$ \\
\hline MSDINTARLP & IGRPESIP & CVGDDIEMILERGQKLC & 849.4781 & $\sqrt{ }$ \\
\hline MSDINTARLP & LRLPPFMIPP & CVGDDIGMVLTRGENLC & 1161.6805 & $\sqrt{ }$ \\
\hline MSDVNATRLP & FNFFRFPYP & CIGDDSASVLGLGESLC & 1215.5938 & $\sqrt{ }$ \\
\hline MSDINATRLP & SSVLPRP & CVGDVDNIILTSREKLC & 736.4304 & $\sqrt{ }$ \\
\hline MSDMNVARLP & ISDPTAYP & CVGGDIHAVLRRGE & 844.4039 & $x$ \\
\hline MSDMNVARLP & ISDPTAYP & CVGGDIHAVLRRGE & 844.4039 & $x$ \\
\hline MSDINVTCLP & FIFWFFWPP & CVGDDAASIIK-GK & 1267.6291 & $x$ \\
\hline MSDINAARLP & FIFPPFFIPP & CVSDDIEMVLTRGE & 1202.6601 & $x$ \\
\hline MSDINTARLP^ & AFFPPFFIPP & CVSDDIEMVLTRGESLC & 1160.6131 & $\sqrt{ }$ \\
\hline MSDINATRLP^ & IPILPIPP & YCSDDANTTLTLGESLC & 840.5545 & $\sqrt{ }$ \\
\hline MSDINATRLP^ & LFLLAALGIP & -SDDADSTLTRGESLC & 1008.6444 & $\sqrt{ }$ \\
\hline MSDTNDARLP^ & LFFWFWFLWP & SVSDDIDSVLNRGEDLC & 1469.7397 & $\sqrt{ }$ \\
\hline MSDINTVCLP & VQKPWSRP & CVGDDIEMILERGEDLC & 978.5472 & $\sqrt{ }$ \\
\hline MSDINTAALP & FFFPPFFIPP & CVSDDIEMVLTRGENLC & 1236.6444 & $\sqrt{ }$ \\
\hline MSDINITRLP & FFPIVFIPP & CIGDDAASIVKQGENLC & 1057.6073 & $\sqrt{ }$ \\
\hline MSDINTVCLP & LQKPWSRP & CVGDDIEMILERGE & 992.5628 & $\mathrm{~N} / \mathrm{A}$ \\
\hline MFDINITRLP & IFWFIYFP & CVGDDVTALLTRGE & 1113.5761 & $\mathrm{~N} / \mathrm{A}$ \\
\hline \multicolumn{5}{|c|}{$\begin{array}{l}{ }^{1} \text { Gray shade indicates MSDIN genes shared by the two strains. Black box for MSDINs present only in strain AsYYH; box of dashed line } \\
\text { for MSDINs present only in the previously reported strain; }{ }^{\wedge} \text { for newly found MSDINs compared to the previous report. }\end{array}$} \\
\hline \multicolumn{5}{|c|}{${ }^{2}$ Red letters present differences in MSDINs from the two strains. } \\
\hline \multicolumn{5}{|c|}{${ }^{3}$ Green letters indicate alternative splicing. } \\
\hline \multicolumn{5}{|c|}{${ }^{4}{ }^{\natural}$ and underlined letters indicate novel cyclic peptides detected with MS and MS/MS. } \\
\hline
\end{tabular}


Table 2

T The MSDIN gene family in Amanita rimosa

\begin{tabular}{|c|c|c|c|}
\hline Leader Peptide & Core Peptide & Recognition Sequence & Monoisotopic Mass \\
\hline MSDINSTRLP & IWGIGCNP & SVGDEVTALLTRGEA & 918.3541 (a-amanitin) \\
\hline MSDINATRLP & IWGIGCNP & SVGDEVTALLASGEA & 918.3541 (a-amanitin) \\
\hline MSDINATRLP & IWGIGCDP & CVGDDVAALTTRGEA & 919.3382 ( $\beta$-amanitin) \\
\hline MSDINATRVP & AWLVDCP & CVGDDISRLLTRGEK & 846.3217 (phallacidin) \\
\hline MSDINATRLP & AWDSKHP & CVGDDVSRLLTRGE & 821.3893 \\
\hline MSDINATRLP & AWDSKHP & CVGDDISRLLTRGE & 821.3893 \\
\hline MSDINATRVP & AWLAECP & CVGDDISHLLTRGE & 770.3494 \\
\hline MSDINASRLP & FFIIIVKP & CGNPYVSDDVNSTLTRGE & 957.6124 \\
\hline MSDINTSRLP & FIPLGIITILP $\square$ & CVSDDVNTTITRGD & 1177.7547 \\
\hline MSDINTACLP & FLFPVIPP & CLSEDANVVVLNSGE & 910.5316 \\
\hline MSDINVTRLP & FFPIVFIPP & $\mathrm{Cl}$ & 1057.6073 \\
\hline MSDINIARLP & IFWFIYFP & CVGDDVDNTLSRGE & 1113.576 \\
\hline MSDINVTRLP & IFLIMFIPP & CIGDDAASILKQGE & 1071.6263 \\
\hline MSDINTSCLP & IFIAFPIPP & CVSDDIQTVLTRGE & 995.5917 \\
\hline MSDTNTACLP & IFIAFPIPP & CVSDDIQTVLTRGE & 995.5917 \\
\hline MSDINASRLP & ILKKPWAP & SVCDDVNSTLTRGE & 933.5872 \\
\hline MSDINVARLP & ISDPTAYP ${ }^{\rrbracket}$ & CVGDDIQAVVKRGE & 844.4039 \\
\hline MSDINATRLP & IIIVLGLIIP & LCVSDIEMILTRGE & 1044.7383 \\
\hline MSDINASRLP & IILAPIIP & CISDDVNTTLTCAE & 830.5702 \\
\hline MSDINTTGLP & HFYNLMPP & CFSDDTGMVLVRGE & 999.4709 \\
\hline MSDINATRLP & HPFPLGLQP & CAGDVDNFTLIKGE & 986.541 \\
\hline MSDINASCLP & LILVANGMAYV & -SDDVSPTLTRGE & 1144.6387 \\
\hline MSDINTARLP & SYIPFPPP & CLSEDTNAVLMLGE & 898.4661 \\
\hline MSDINTARLP & SYIPFPPP & CLSEDTNAVLMLGE & 898.4661 \\
\hline MSDINTSRFP & SYGYRAFP & CVGDDVEMVLMHGE & 941.4468 \\
\hline MSDINVTRLP & VLVFIFFLP & CISDDAASIIKLGE & 1075.6543 \\
\hline MSDIDTTRLP & LILFTLQP & SIGDDVNPTLTRGEK & 925.5709 \\
\hline MSDIHAARLP & FPTRPVFP & SAGDDMIEVVLGRGE & 941.5196 \\
\hline MSDNNAARLP & FYFYLGIP & SDDAHPILTRGERLA & 1000.5058 \\
\hline MSDTNTARLP & ILFIQLEIP & CISDDVHPVLTRGE & 1066.6426 \\
\hline MSDVNTTRLP & FNFFRFPYP & CICDDSEKVLELGE & 1215.5865 \\
\hline MSEINTARFP & NHGHRTIP & CVGDDIEMVLMHGE & 912.4678 \\
\hline
\end{tabular}

\footnotetext{
${ }^{1} \square$ and underlined letters indicate novel cyclic peptides detected with MS and MS/MS.

${ }^{2}$ The monoisotopic masses are for unmodified cyclic peptides based on MSDIN core peptides, except for major toxins.
} 


\begin{tabular}{|llll|}
\hline Leader Peptide & Core Peptide & Recognition Sequence & Monoisotopic Mass \\
\hline MSEINTSRLP & LVFIPPYFAP & CVSDDIQMVLTLGE & 1144.632 \\
\hline MFDMNTTCLP & GFIIYAYV & -GDDVNHTLTRGE & 926.4901 \\
\hline MLDINTARLP & FSLPTFPP & CVSDEIDVVLKRGE & 886.4588 \\
\hline MLDINATRFP & LGRPTHLP & CVGDDVNYIL & 871.5027 \\
\hline MTDINDARLP & ILLLIFFWIP & CANDDDENILNRG & 1255.7732 \\
\hline MTDINDTRLP & FVWILWLWLA & CVGDDTSILNRGE & 1327.748 \\
\hline MPDINVTRLP & LLIIVLLTP & CISDDNNILNRGK & 975.6732 \\
\hline 1■ and underlined letters indicate novel cyclic peptides detected with MS and MS/MS. \\
\hline 2The monoisotopic masses are for unmodified cyclic peptides based on MSDIN core peptides, except for major toxins. \\
\hline
\end{tabular}


Table 3

૫ The MSDIN gene family in Amanita exitialis

\begin{tabular}{|c|c|c|c|}
\hline Leader Peptide & Core Peptide & Recognition Sequence & Monoisotopic Mass \\
\hline MSDINATRLP & IWGIGCNP & CVGDDVTSVLTRGEA & 918.3541 (a-amanitin) \\
\hline MSDINATRLP & IWGIGCDP & CVGDDVTALLTRGEA & 919.3382( $\beta$-amanitin) \\
\hline MSDINATRLP & AWLVDCP & CVGDDVNRLLTRGE & 846.3217(phallacidin) \\
\hline MSDINATRLP & AWLTDCP & CVGDDVNRLLTRGE & 786.3443 \\
\hline MSDINTTRLP & FVFVASPP & CVGDDIAMVLTRGE & 844.4556 \\
\hline MSDINTARLP & FIWVFGIP & G-DDIGTVLTRGEK & 959.5342 \\
\hline MSDINLTRLP & GIIAIIP & CVGDDDDVNSTLTRGQ & 677.4549 \\
\hline MSDINATRLP & IILAPVIP & CISDDNDP-TLTRGQ & 816.5546 \\
\hline MSDINTARLP & IPIPPFFFP & FVSDDIEIVLRRGEK & 1055.5917 \\
\hline MSDINTARLP & IPIPPFFFP & FVSDDIEIVLRRGEK & 1055.5917 \\
\hline MSDINATRLP & IGRPQLLP & CVGGDVNYILISGEK & 874.5461 \\
\hline MSDINPTRLP & IFWFIYFP & CVSDVDST-LTRGE & 1113.5761 \\
\hline MSDINTARLP & IYRPPFYALP & CVGDDIQAVLTRGE & 1217.6670 \\
\hline MSDINTARLP & IIWIIGNP & CVSDDVERILTRGE & 906.5400 \\
\hline MSDINVIRAP & LLILSILP & CVGDDIEV-LRRGE & 862.5964 \\
\hline MSDINATRLP & LFFPPDFRPP & CVGDADNFTLTRGEK & 1213.6357 \\
\hline MSDINATRLP & LFFPPDFRPP & CVGDADNFTLTRGE & 1213.6357 \\
\hline MSDINVIRLP & SMLTILPP & CVSDDASNTLTRGE & 852.4852 \\
\hline MSDINTARLP & VFSLPVFFP & -SDDIQAVLTRGE & 1033.5709 \\
\hline MSDINVTRLP & VFIFFFIPP & CVGDGTADIVRKGEK & 1107.6230 \\
\hline MSDINATRLP & VWIGYSP & CVGDDCIALLTRGE & 802.4086 \\
\hline MSDINATRLP & VWIGYSP & CVGDDCIALLTRGE & 802.4086 \\
\hline MTDINDTRLP & FIWLLWIWLP & SVGDD-NNILNRGEE & 1367.7867 \\
\hline \multicolumn{4}{|c|}{${ }^{1} \rrbracket$ and underlined letters show novel and known cyclic peptides detected with MS and MS/MS. } \\
\hline
\end{tabular}

Transcriptome of As

As was chosen to be sequenced via Illumina RNA-Seq technique, as this was a readily available species. The specific sample was collected only a few meters apart from the strain AsYYH. In total $11.7 \mathrm{~Gb}$ clean reads were obtained. The assembled transcriptome yielded 46.1 Mb with 25,453 unigenes. BLAST search against the transcriptome with MSDINs from the two As genomes produced 24 MSDINs, four more than those in our previous result [14]. These four sequences were used as queries to re-search the genome, and the result confirmed their presence (Table 1). For the previously sequenced genome, 22 out of the 24 MSDIN genes were found to be expressed at the transcription level, i.e., $91.7 \%$ of the MSDINs were expressed (Table 1). For the new genome of the strain AsYYH, 23 out of 25 genes, i.e. $92.0 \%$, were expressed (Table 1). Our result showed that most of MSDINs were expressed at the transcription level in As. Regarding the gene structure, exons and introns were conserved among most of the MSDIN genes, while alternative splicing was detected in two of the MSDIN transcripts marked in green in Table 1. The expressed MSDINs were the focus for potential cyclic peptide production in the following MS and MS/MS analyses. 
LC-HRMS and LC-MS/MS analyses on novel cyclic peptides in As

With the Agilent LC-HRMS platform, correlations between measured masses and predicted peptides based on genomic data were carefully assessed. There were no linear versions of these peptides detected. Further, hydroxylation(s), sulfoxidation and cross-bridging, by themselves or by various combinations, were not detected on predicted linear or cyclic peptides. However, two matches were found between theoretical and measured masses of two predicted cyclic peptides. These two matches corresponded to the cyclized core peptide sequences of TFLPPLFVPP (named CyIG1) and AFFPPFFIPP (named CyIG2) without further modifications, respectively. The molecular formula for the candidate new cyclic peptide CyIG1 is $\mathrm{C}_{59} \mathrm{H}_{84} \mathrm{~N}_{10} \mathrm{O}_{11}$, and the theoretical molecular weight is $1109.6394\left[\mathrm{M}+\mathrm{H}^{+}\right.$. The measured molecular weight was $1109.6398\left[\mathrm{M}+\mathrm{H}^{+}\right.$, with mass discrepancy of $0.36 \mathrm{ppm}$ (Fig. 3A). The molecular formula for CylG2 is $\mathrm{C}_{65} \mathrm{H}_{80} \mathrm{~N}_{10} \mathrm{O}_{10}$ with the theoretical molecular weight at $1161.6131[\mathrm{M}+\mathrm{H}]^{+}$, and the measured molecular weight was $1161.6161[\mathrm{M}+\mathrm{H}]^{+}$, with mass discrepancy of $2.53 \mathrm{ppm}$ (Fig. 3B). Two adduct ions of $[\mathrm{M}+\mathrm{Na}]^{+}$and $[\mathrm{M}+\mathrm{K}]^{+}$were shown in the figure as well. CylG1 and CyIG2 were treated as candidate new cyclic peptides for further characterization.

In order to determine amino acid composition of CyIG1 and CyIG2, the candidate cyclic peptides were submitted to LC-MS/MS. The resultant spectra were first analyzed via Center for Computational Mass Spectrometry (CCMS) using the database of UniProtKB/Swissport (Fig. 3C). The obtained peptide sequence for CyIG1 was PPLVFTPPLE, only one amino acid different at the C-terminal (E vs. F, one letter codes used here and below for easy comparison), and this was due to that the CCMS only used linear peptide databases (Fig. 3C underlined). The molecular weight of $F$ is 165.19 and losing $\mathrm{H}_{2} \mathrm{O}$ will make the mass 147.18 , close to that of $\mathrm{E}(147.13)$ and therefore accounting for the presence of $\mathrm{E}$ over F. For Cy $1 \mathrm{G} 2$, similar processes were applied, and discrepancy was also found at the last predicted amino acid (Fig. 3D underlined). Some of our peptides did not return any results with CCMS, and they were then analyzed with other platforms (Mascot, pNove and XCMS). In general, the results were largely in line with the above. Although the automated pipelines offered some evidence, we mostly relied on the following manual process to determine the peptide sequences.

Manual amino acid composition analysis was mostly based on y-type fragmentation of linear peptides. For CylG1, fragment ions were calculated using the core peptide, and the result of searching for these ions in the MS/MS spectrum was shown in Fig. 3E. Every fragment ion was manually checked and confirmed. Illustrated in Fig. 3E, y-type fragments (y2 to y9) were shown to be in strong agreement with the core peptide, and all the amino acids could be readily explained by the $y$-type ions. Immonium ions for $P$, $L$ and $F$ were also identified for CyIG1. As a result, CyIG1 was assigned as a novel cyclic peptide with the amino acid composition and combinations matching the circular MSDIN core peptide sequence Cyclo(TFLPPLFVPP) (Fig. 3C, E). CyIG2 underwent the same analyses, in which case immonium ions for P, I and $\mathrm{F}$ were identified. Similarly, $\mathrm{y}$-type fragments (y2 to y9) were shown to be in strong agreement with the core peptide, and all the amino acids complied with the y-type fragment ions (Fig. 3D, F). In conclusion, CyIG2 was confirmed to be a novel cyclic peptide with the sequence Cyclo(AFFPPFFIPP). The peptide only differed from antamanide, Cyclo(FFVPPAFFPP), by one amino acid (I vs. V) when they were compared in circular structures.

\section{Cloning MSDIN genes and LC-HRMS analysis in As AsBJ strain}

Because the two cyclic peptides, CylG1 and CylG2, were not detected in the AsBJ strain, we were intrigued to see if the corresponding MSDINs were present. All attempted PCR reactions came back negative, while all the controls for $\alpha$ - and $\beta$-amanitins were positive. The result was consistent with that the lack of the two cyclic peptides in AsBJ was due to the absence of the two corresponding MSDIN genes.

Novel cyclic peptides in other Amanita species

CyIG1 and CyIG2 in As were our first effort towards finding novel cyclic peptides in the genus. Taking advantage of this genome-guided approach, we analyzed three other Amanita species, i.e., A. pallidorosea (Apa), Ae, and Ar. In total, 10 additional new cyclic peptides were discovered (Table 4). Relevant data analyses of mass spectrometry were included in the supplementary information (Additional file 1: Figures S1-S6). Three new cyclic peptides were found in Ar, and their sequences, in the same order of their corresponding MSDIN core peptides, were Cyclo(ISDPTAYP), Cyclo(FIPLGIITILP) and Cyclo(FPTRPVFP) (Additional file 1: Figures S1 and S4), which were named $\mathrm{CylH} 1, \mathrm{CylH} 2$, and $\mathrm{CylH} 3$ respectively. Five new cyclic peptides were found in Apa, and their sequences were Cyclo(EFIVFGIFP), Cyclo(FVIIPPFIFP), Cyclo(YFFNDHPP), Cyclo(TIHLFSAP) and Cyclo(MHILAPPP) (Additional file 1: Figures S2 and S5), which were named Cyll1, Cyll2, Cyll3, Cyll4, and Cyll5, respectively. Further information on MSDIN genes in Apa were included in Additional file 1: Table S1. Two new cyclic peptides were found in Ae, and their peptide sequences were Cyclo(FVFVASPP) and Cyclo(LFFPPDFRPP) (Additional file 1: Figures S3 and S6), which were named CylJ1 and CylJ2 respectively. An previously known cyclic peptide called amanexitide with the sequence Cyclo(VFSLPVFF) [16] was also found in this study (Additional file 1: Figures S7). In conclusion, 12 novel and one known cyclic peptides were discovered in the four sequenced species (Talbe 4). 
Table 4

Twelve novel and one known cyclic peptides discovered in Amanita subjunquillea, A. rimosa, A. exitialis and A. pallidorosea.

\begin{tabular}{|c|c|c|c|c|c|}
\hline Species & Cyclopeptide sequence & Molecular formula & Theoretical(m/z) & Measured(m/z) & $\delta(\mathrm{ppm})$ \\
\hline \multirow[t]{2}{*}{ A. subjunquillea } & TFLPPLFVPP (CyIG1) & $\mathrm{C}_{59} \mathrm{H}_{84} \mathrm{~N}_{10} \mathrm{O}_{11}$ & 1109.6394 & 1109.6398 & 0.36 \\
\hline & AFFPPFFIPP (CylG2) & $\mathrm{C}_{65} \mathrm{H}_{80} \mathrm{~N}_{10} \mathrm{O}_{10}$ & 1161.6131 & 1161.6161 & 2.53 \\
\hline \multirow[t]{3}{*}{ A. rimosa } & ISDPTAYP ${ }^{*}(\mathrm{CylH} 1)$ & $\mathrm{C}_{39} \mathrm{H}_{56} \mathrm{~N}_{8} \mathrm{O}_{13}$ & 845.4039 & 845.4040 & 0.36 \\
\hline & FIPLGIITILP (CylH2) & $\mathrm{C}_{61} \mathrm{H}_{99} \mathrm{~N}_{11} \mathrm{O}_{12}$ & 1178.7547 & 1178.7555 & 0.64 \\
\hline & FPTRPVFP (CylH3) & $\mathrm{C}_{48} \mathrm{H}_{67} \mathrm{~N}_{11} \mathrm{O}_{9}$ & 942.5196 & 942.5191 & 0.53 \\
\hline \multirow[t]{5}{*}{ A. pallidorosea } & EFIVFGIFP (Cyll1) & $\mathrm{C}_{56} \mathrm{H}_{75} \mathrm{~N}_{9} \mathrm{O}_{11}$ & 1050.5658 & 1050.5694 & 3.35 \\
\hline & FVIIPPFIFP (CyII2) & $\mathrm{C}_{65} \mathrm{H}_{90} \mathrm{~N}_{10} \mathrm{O}_{10}$ & 1171.6914 & 1171.6941 & 2.30 \\
\hline & YFFNDHPP (Cyll3) & $\mathrm{C}_{51} \mathrm{H}_{59} \mathrm{~N}_{11} \mathrm{O}_{12}$ & 1018.4417 & 1018.4421 & 0.35 \\
\hline & TIHLFSAP (Cyll4) & $\mathrm{C}_{42} \mathrm{H}_{62} \mathrm{~N}_{10} \mathrm{O}_{10}$ & 867.4723 & 867.4733 & 1.14 \\
\hline & MHILAPPP (CylI5) & $\mathrm{C}_{41} \mathrm{H}_{64} \mathrm{~N}_{10} \mathrm{O}_{8} \mathrm{~S}$ & 857.4702 & 857.4714 & 1.39 \\
\hline \multirow[t]{3}{*}{ A. exitialis } & FVFVASPP (CylJ1) & $\mathrm{C}_{44} \mathrm{H}_{60} \mathrm{~N}_{8} \mathrm{O}_{9}$ & 845.4556 & 845.4582 & 3.07 \\
\hline & LFFPPDFRPP\# (CylJ2) & $\mathrm{C}_{63} \mathrm{H}_{83} \mathrm{~N}_{13} \mathrm{O}_{12}$ & 1214.6357 & 1214.6357 & 0.00 \\
\hline & VFSLPVFFP^ & $\mathrm{C}_{56} \mathrm{H}_{75} \mathrm{~N}_{9} \mathrm{O}_{10}$ & 1034.5709 & 1034.5734 & 1.97 \\
\hline \multicolumn{6}{|c|}{${ }^{1 *}$ indicates that the sequence has been found in A. subjunquillea, A. pallidorosea and A. rimosa. } \\
\hline \multicolumn{6}{|c|}{${ }^{2 \#}$ The superscript number 2 indicates this sequence has two copies. } \\
\hline \multicolumn{6}{|c|}{${ }^{{ }^{\wedge}}$ Indicates amanexitide. } \\
\hline
\end{tabular}

LC-HRMS analysis on As mycorrhizae and gene cloning for major toxins

Successful tracing of As hyphae to plant roots were carried out in this study. Figure 4A illustrated a fresh fruiting body of As showing apparent association with a network of plant roots, and 4B displayed a cross section of a selected root tip with signs of mycorrhizal symbiosis. All four major toxins, i.e., a-amanitin, $\beta$-amanitin, phalloidin and phallacidin, were detected in LC-HRMS, with mass discrepancies of $2.12,0.50,0.76$, and $2.93 \mathrm{ppm}$, respectively (Fig. 5). Cloning of the MSDINs for the major toxins was successful and the corresponding MSDINs of the toxins were shown above each section of the figure. We were not able to quantify the toxins because of limited amount of the material. However, a-amanitin was clearly the most significant as it showed as a robust peak in the HPLC chromatograms.

\section{Discussion}

To date, most cyclic peptides in Amanita are first discovered from A. phalloides with a few exceptions [6]. It has been suspected that lethal Amanita species could produce significant more cyclic peptides than what have been discovered $[1,6]$. The genome-guided approach adopted in this study identified 12 novel cyclic peptides in four lethal Amanita species, providing strong support in this perspective. Around half of these peptides did not produce discernable peaks in HPLC chromatograms, indicating MS is highly sensitive in identifying these molecules. The discovered cyclic peptides lack further modifications besides cyclization and therefore can be readily synthesized for the purpose of screening for useful activities. Cyclic peptide pools in different species, even in different strains, have distinctions, although the core set (major toxins) is relatively stable. As a result, the collection of the peptides in dozens of known lethal species in the genus should constitute a large cyclic peptide reservoir, potentially valuable for useful biological activities. Cyclic peptides from Amanita including the toxins are highly valuable resources. a-Amanitin has been shown to have high potential in cancer research and treatment [29-31]. Phalloidin and phallacidin are valuable in cell research as generic molecular tools [32]. Antamanide functions as an antitoxin, 
reversing the effort of phalloidin [33], and researchers now show that antamanide inhibits the mitochondrial permeability transition pore by targeting the regulator cyclophilin D [24]. In addition, cycloamanides and the related peptides possess potent activities useful in immunity-related medical situations [25, 26]. Logically, unknown cyclic peptides in Amanita species could be a valuable source for useful activities.

Cyclic peptide toxins in Amanita mushrooms have been considered to carry out a protective role against insects and other animals for the fruiting bodies, although the thought rarely materializes in publications. The finding of all four major toxins in As mycorrhizae was a rather unanticipated outcome. This was completely unknown to science mainly due to the fact that it is difficult to trace the mycelia from the mushrooms to the mycorrhizae, and these fungi are largely not culturable at the moment. As part of our other ongoing project, we investigated the toxin profile in the As mycorrhizae. The unexpected result is clearly against the previous hypothesis that the toxins were merely present in fruiting bodies [11]. This may be an indication that these toxins have role(s) in mycorrhizal symbiosis in lethal Amanita species. In Galerina marginata, the toxin production is detected in mycelia cultured in artificial media [34], serving as another example that the toxins could be produced outside the fruiting bodies. It would be close to a pure conjecture at this point to comment on the roles of the toxins in the mycorrhizal association. It could be that the fungi need to fend off animals or other fungi in soil, and it is also possible that the toxins play other unknown role(s). Given the molecular mechanism of a-amanitin, i.e. inhibition of RNA polymerase II, could it have regulatory function at the level of transcription? Does it have anything to do with the establishment of mycorrhizae in lethal Amanita? Amanita phalloides has rapidly spread from Europe to North America [35]; could the cyclic peptides aid in the process? It is largely blank in this area and perhaps all we can do at present is to keep an open mind. The pattern of the HPLC chromatograms on the mycorrhizae were very different from those of fruiting bodies. Although we were not able to quantify these toxins, a-amanitin was clearly the most significant shown as a major peak in the HPLC analysis. In contrast, the other three were present as small bumps in the chromatograms.

We believe that the genome-guided approach with mass spectrometry offered reliable results in this study. Regarding the data of LCHRMS, the measured molecular masses of the obtained cyclic peptides were all within $5 \mathrm{ppm}$ mass discrepancies. MS/MS analyses showed that amino acid composition and combinations in these molecules matched nicely to their corresponding MSDIN core peptide sequences. When the AsBJ strain of As was analyzed, it was found through PCR that, the corresponding MSDINs for the two novel cyclic peptides were missing, coinciding with that the two novel peptides, CyIG1 and CylG2, were absent from the strain. As another line of support, Cyclo(VFSLPVFFP) was found in Ae in this study, and this cyclic peptide was also discovered via biochemistry from the same species in 2011 [16]. These authors also showed that MS/MS analysis for this unmodified cyclic peptide was reliable. Last, manual analyses of MS and MS/MS data were the key for the pipeline. MS required good sample preparation and separation. Suitable MS/MS spectra oftentimes needed tweaking with collision energy and sample amounts. Fragment ions frequently could be recognized only by manual inspection.

Most of the MSDINs were expressed at the transcription level in As, as suggested by the RNA-Seq data. Previous studies detected as many as half of MSDINs expressed in A. phalloides and A. bisporigera [15], and additional expressed sequences were cloned from other Amanita species through RT-PCR $[36,37]$. In our results with deep sequencing at $11.7 \mathrm{~Gb}$ data yield, around $92 \%$ MSDINs were shown to have corresponding transcripts in both strains. This indicates MSDINs are mostly real, active genes, which could potentially lead to production of many more true cyclic peptides than previously known in the genus. Our results also strongly suggest that, the amanitin biosynthetic pathway is highly versatile, capable of producing a wide range of cyclic peptides.

Strain differences were apparent in this study. It was observed that the AsBJ strain of As showed differential cyclic peptide production. In light of this, the strain AsYYH was sequenced, and similar results were obtained. Out of 27 MSDIN genes discovered in the two As genomes, 22 were shared, with two specific to the former sequenced strain [14], and three unique to AsYYH. The results showed that even at strain level, MSDIN gene sets from independent genomes can vary. The two independent strains sequenced were from two locations that were only a few hundred meters apart. This result suggests that MSDIN genes are highly dynamic, except for the core ones encoding major amatoxins and phallotoxins.

Regarding the structures of the novel cyclic peptides, CyIG1 and CyIG2 have a characteristic amino acid composition with double Pro residues, no Trp and Cys, and without any further posttranslational modifications. They and amanexitide share similarities to antamanide in that they are all decapeptides with a conserved sequence of XXXPPXXXPP; the two pairs of Pro residues are frequently found in MSDINs. Without Trp and Cys, sulfoxidation and tryptathionine are prohibited. According to the MS/MS data, hydroxylation on the 13 obtained peptides was not detected. Pro (100\%), Phe (84.6\%) and Ile (53.8\%) were the most frequent residues in these cyclic peptides. CyIG2 is very similar to antamanide with only one amino acid difference (lle vs. Val). In Ar, the new peptide Cyclo(FIPLGIITILP), CyIH2, has 11 amino acids, which is by far the longest in all Amanita cyclic peptides discovered. Despite of some structure similarities, the biological activities of these peptides require further study. 
Posttranslational modifications other than cyclization, such as hydroxylation and sulfoxidation, were not detected in this study. The observation is probably due to that our current model pertaining to how these modifications occur and in which order, may not be entirely correct. And it is also possible that there may be other unknown modifications involved, which introduces more possibilities. Most of the cyclic peptides found in this study are present in low concentrations and therefore cannot be readily purified to a significant quantity. However, being without further modification does convey an advantage, as they can be readily synthesized at reasonable costs. Part of our on-going project is to produce and to screen these peptides against various targets.

\section{Conclusion}

This report provided a genome-guided approach for discovering cyclic peptides in lethal Amanita mushrooms. Three deadly Amanita species were sequenced, and in total 37 novel MSDIN genes discovered. Majority of the MSDIN genes were found to be expressed at the mRNA level in A. subjunquillea. Using mass spectrometry, 12 new cyclic peptides were identified, which are potentially valuable for potent activities. Our results show that the amanitin biosynthetic pathway is highly versatile, capable of producing a wide range of cyclic peptides. This is also the first report on toxins expressed in Amanita mycorrhizae, shedding light on their possible role(s) at the stage of mycorrhizal symbiosis.

\section{Methods}

Collection and preservation of samples

Fresh fruiting bodies of strains of As (strain AsYYH and the ones for RNA-Seq) were collected from Kunming, Yunnan Province of China, about 300 meters apart from the previously reported one (14). An additional strain AsBJ was collected in Beijing, China for MS comparison. Fresh fruiting bodies of Ae, Ar and Apa were collected in the Guangzhou, Hunan and Shandong provinces of China, respectively. For mycorrhizal collections, the same site for As was chosen. Once a fresh fruiting body of As was located, soil was carefully removed to expose plant roots, and root tips with signs of mycorrhizal association were cut off and rinsed in $\mathrm{ddH}_{2} \mathrm{O}$ several times to remove dirt and debris. All the above samples were immediately buried in dry ice on site, transferred to liquid nitrogen tanks the same day, freeze-dried, and then stored in $-80^{\circ} \mathrm{C}$. All the mushrooms were taxonomically identified according to previous studies [2,5]. Hand-cut sections were made from fresh As mycorrhizae, stained with Congo red, and viewed under a microscope (Leica DM1000 LED). Genome and transcriptome sequencing

The sequencing platform for the genomes of Ae, Ar and the strain AsYYH of As was PacBio Sequel at NextOmics Biosciences, Wuhan, China. Sequencing and assembly were carried out using the company's standardized pipeline. High quality DNA was extracted as described before [14], and a 20-Kb library was constructed using a PacBio template prep kit and was analyzed by Agilent 2100 Bioanalyzer for quality control. After the completion of the library, the DNA template and enzyme complex were transferred to the Sequel sequencer for real-time single molecule sequencing. Illumina HiSeq X10 platform was used for nucleotide level correction, based on a 350 bp library and the company's a standard method. For the following analyses, two additional genomes of As and Apa were adopted from our previous studies [14].

One species, As was chosen for transcriptome sequencing largely due to its availability. The process was carried out via standardized pipeline at NextOmics Biosciences, Wuhan, China. The library was constructed after the samples passed quality inspection. The cDNA library was constructed by magnetic bead enrichment. Clean reads were obtained from Illumina RNA-Seq platform, which were then aligned to the two As genomes using HISAT2 software [38], and transcriptome assembly was performed using StringTie under the default parameter [39].

Cloning of MSDINs from AsBJ strain and mycorrhizae of As

Coding sequences of MSDINs from As (included a-amanitin, $\beta$-amanitin, CyIG1 and CyIG2) were obtained by RT-PCR using primers based on the genomic data. For a-amanitin encoding gene, the forward primer was 5'-CCAACCAAGGTAGGGAACG-3', and the reverse primer was 5'-TGGACATCTAGTATCATCGTTCG-3'. There were two MSDINs both encoding $\beta$-amanitin. Two sets of primers were designed accordingly. For the first MSDIN, MSDINATRLPIWGIGCDPCIGDDVTALLTRGEALC, the forward primer was 5'-CTTGCAGGATTGATTTTGTAGGAT-3' and the reverse primer was 5'-CTGAATGTGCGAATGAGAATAGC-3'. For the second MSDIN, MSDINATRLP IWGIGCDPCVGDEVTALLTRGEALC, the forward primer was 5'-CCGCGACTTACAGGATTGAT-3', and the reverse primer was 5'-AAACAGTGCATTATTCGGTCAT-3'. For CyIG1 and CyIG2, the forward primers were 5'-GGTTTGCCTCTGCCTGAC-3' and 5'- GGTTTGCCTCTGCCTGACT-3', and the reverse primers were 5'GCTCTGTGCGACTTGTGG-3' and 5'- TCAAGCCACCGCAATAGAA-3', respectively. The PCR reactions were carried out under standard conditions. 
With the As mycorrhizae, for $\alpha$ - and $\beta$-amanitins, the primers were as the above. For phalloidin, the forward primer was $5^{\prime}$ -

GAAACCTCTCAACCGCAATGT-3', and the reverse primer was 5'- AAAGGATTGAAAAAGCACACG-3'. For phallacidin, the forward primer was 5'- GACCCCAGCTCTAAATCACAATG-3', and the reverse primer was 5'- CGCAGATCATTTACGTGGGTTTT-3'.

Extraction of cyclic peptides

Roughly $0.05 \mathrm{~g}$ of freeze-dried material for all samples was ground to fine powder in a mortar and pestle with liquid nitrogen. Then $1 \mathrm{~mL}$ extraction buffer containing absolute methanol: water: $0.01 \mathrm{M}$ hydrochloric acid (5: 4: 1) was added. The mixture was heated in a water bath at $75^{\circ} \mathrm{C}$ for $15 \mathrm{~min}$ before centrifugation at 12,000 rpm for $10 \mathrm{~min}$. The supernatant was transferred to a new $1.5 \mathrm{~mL}$ centrifuge tube, filtered with a $0.22 \mu \mathrm{m}$ PES syringe filter (BS-PES-22, Biosharp), and then stored in $-80{ }^{\circ} \mathrm{C}$ before use.

HPLC analysis

The HPLC method analyses were performed using a reversed-phase C18 column on an Agilent 1260 Infinity II HPLC system equipped with a UV detector (Agilent Technologies Inc). Separations were carried out on an InfinityLab Poroshell 120 EC-C18 reverse phase HPLC column $\left(4.6 \times 100 \mathrm{~mm}\right.$ I.D., particle size $2.7 \mu \mathrm{m}$, Agilent Technologies) at $28^{\circ} \mathrm{C}$. The mobile phases were (A) $0.02 \mathrm{M}$ aqueous ammonium acetateacetonitrile (90:10, v/v) and (B) 100\% acetonitrile. The pH of solvents A was adjusted to 5.0 with glacial acetic acid. All solutions were prepared with HPLC grade reagents, and were degassed before use. For HPLC separation, the flow rate was $0.5 \mathrm{ml} / \mathrm{min}$ with a step of constant $100 \%$ solution A for 2 min, followed by a gradient from 100\% solution A to 100\% solution B in 8 min. The absorbance of the elution was monitored at 280 and $295 \mathrm{~nm}$.

Mining MSDIN data

All nucleotide sequences of MSDINs from their genomes and the As transcriptome were obtained through standalone BLAST searches (NCBI BLAST ${ }^{+}$2.6.0) with query MSDIN sequences from A. bisporigera and G. marginata, which are well characterized by our molecular and biochemical approaches [40,41]. In addition, MSDINs with high divergence at the core region from our previous reports were added as queries for more thorough excavation of potential MSDIN genes [14]. In the case of As, the resulted MSDIN sets were used as queries to further cross-search the two genomes and the As transcriptome for the purpose of finding MSDINs with high divergence.

Predicted molecular masses of candidate peptide sequences

To obtain molecular masses of predicted peptides based on MSDIN sequences, calculation websites

(https://www.ncbi.nlm.nih.gov/CBBresearch/Yu/webresources.html, and https://www.expasy.org/) were adopted for calculating monoisotopic masses. This report mainly used the NCBI online calculation under the following conditions: Coarse-grained isotopic distribution mass accuracy $(\mathrm{Da})=1$, Fine-grained isotopic distribution mass accuracy $(\mathrm{Da})=0.01$, and the algorithm based on polynomial. Linear peptides adopted the amino acid sequences directly for core regions of MSDIN genes. Cyclized versions equaled to the linear versions minus a water molecule. Besides cyclization, this study attempted to predict other possible posttranslational modifications, including hydroxylation, sulfoxidation and bridge formation. One hydroxylation adds one 0 atom, which can multiply by up to 4 according to known amatoxins. Sulfoxidation adds an $\mathrm{O}$ atom, which only happens to the peptides containing Cys and Trp. The bridge formation between Trp and Cys loses two $\mathrm{H}$ atoms, resulting in a structure called tryptathionine [42]. How many and in which order these modifications would occur to a given MSDIN-related peptide are unknown. Our strategy was to try different combinations and look for matches in LC-HRMS.

LC-MS and LC-MS/MS analyses

HPLC separation described as above was coupled with Agilent 6540 UHD precision mass Q-TOF LC/MS (Agilent Technology) equipped with an electrospray source. Eluant was monitored in positive ESI mode with the capillary voltage at $3.5 \mathrm{kV}$. The drying gas $\left(\mathrm{N}_{2}\right)$ temperature was $350^{\circ} \mathrm{C}$ and the flow rate was $8 \mathrm{~L} / \mathrm{min}$. The mass scan range was $500-1700 \mathrm{~m} / \mathrm{z}$. The electrospray electrical (ESI) was performed in a positive mode. For collision energy in MS/MS analysis, a range of 10 to $70 \mathrm{eV}$ was applied.

After LC-MS/MS data were obtained, amino acid composition and combinations of candidate cyclic peptide was investigated first through the platform at Center for Computational Mass Spectrometry (CCMS) based on UniProtKB/swiss-port databased

(https://proteomics.ucsd.edu/ProteoSAFe/). The workflow used MS-GF plus (V1.3.0) on the website by extracting masses of fragments using Agilent Mass Hunter v8.0.0 (Agilent Technology). In detail, the fragmentation diagrams were saved as MGF files and uploaded to CCMS [43]. When no results were obtained with CCMS, other platforms were included in the MS/MS analysis, including Mascot (with NCBIprot database), pNove v3.1 [44], and XCMS online [45]. MS Convert (http://proteowizard.sourceforge.net/tools.shtml) was used for obtaining suitable file formats for each application.

All results from the above online tools were further confirmed or corrected via a thorough manual pipeline. First, high quality MS/MS spectra were obtained by optimizing the energy in the Q-TOF process. Best spectra were selected by choosing the ones with the most $y$ -

Page $12 / 20$ 
type ions characteristic to certain amino acids. In some cases, increased amounts of samples were applied for optimal MS/MS spectra. Second, common fragmentation patterns for linear peptides were adopted for analyzing unmodified cyclic peptides because our preliminary results suggested that they were useful. Third, y-type ions for each MS/MS spectrum were determined based on core peptides of MSDINs using Molecular Weight Calculator v6.50 (http://omics.pnl.gov). Last, immonium ions were searched based on amino acid compositions. Only in situations that most or all amino acids (by themselves or in the right combinations) in a given candidate cyclic peptide matched a MSDIN sequence, did we call the cyclic peptide real with the sequence designated by the core region of the MSDIN gene.

\section{Declarations}

\section{Acknowledgements}

This research was supported by the Strategic Priority Research Program of the Chinese Academy of Sciences (Grant no. XDB31000000), National Natural Science Foundation of China (Grant no. 31772377 and 31972477), Yunnan Key Laboratory for Fungal Diversity and Green Development, Kunming, Yunnan, Scientific Research Foundation of the Education Department of Human Resources and Social Security of Yunnan Province, China, and Scientific Research Foundation of Kunming Institute of Botany, Chinese Academy of Sciences. We have profound gratitude to Jonathan $\mathrm{D}$. Walton for his very kind assistance for the past 12 years, and we are terribly sorry for his recent passing. We also thank Gengshen Wang and Yunjiao Lüli for their kind help on initial version of the manuscript. In addition, we thank Tai-Hui Li and Wang-qiu Deng for helping collect fruiting bodies of $A$. exitialis.

\section{Authors' contributions}

HL and SWZ designed and carried out the genome sequencing, LC-MS/MS and the analyses on mycorrhizae; SWZ did the online database analysis. XCL and XL performed gene cloning and helped write the manuscript. ZHC and GHL collected the samples. HL assembled and analyzed the transcriptome. ZLY helped design the study and helped improve the final manuscript. HL and SWZ prepared the manuscript. All authors read and approved the final manuscript.

\section{Availability of data and materials}

The complete datasets of MS/MS analysis for all 13 cyclic peptides in this study are available from the corresponding author on reasonable request.

\section{Ethics approval and consent to participate}

This article does not contain any studies with human participants or animals performed by any of the authors.

\section{Consent for publication}

All authors have given consent for publication.

\section{Competing interests}

The authors declare that they have no competing interests.

\section{Author details}

${ }^{1}$ Yunnan Key Laboratory for Fungal Diversity and Green Development, Kunming Institute of Botany, Chinese Academy of Sciences, Kunming 650201, Yunnan, China. ${ }^{2}$ CAS Key Laboratory for Plant Diversity and Biogeography of East Asia, Kunming Institute of Botany, Chinese Academy of Sciences, Kunming 650201, Yunnan, China. ${ }^{3}$ College of Life Science, Hunan Normal University, Changsha 410081, China. ${ }^{4}$ Department of Environmental Science and Engineering, Kunming University of Science and Technology, Kunming 650091, Yunnan, China. ${ }^{5}$ Yunnan University, Kunming 650091, China. ${ }^{6}$ University of Chinese Academy of Sciences, Beijing 100049, China.

\section{References}

1. Wieland T. Peptides of poisonous Amanita mushrooms.New York: Springer;1986.

2. Yang ZL. Atlas of the Chinese species of Amanitaceae. Beijing: Science Press;2015.

3. Chen ZH, Yang Z, Tolgor B, Li T. Poisonous mushrooms: recognition and poisoning treatment. Beijing: Science Press;2016. 
4. Bresinsky A. A colour atlas of poisonous fungi: a handbook for pharmacists, doctors, and biologists. CRC Press;1990.

5. Cui YY, Cai Q, Tang LP, Liu JW, Yang ZL. The family Amanitaceae: molecular phylogeny, higherrank taxonomy and the species in China. Fungal Divers. 2018;91:5-230.

6. Walton JD. The cyclic peptide toxins of Amanita and other poisonous mushrooms. Switzerland: Springer International Publishing AG;2018.

7. Lynen F, Wieland U. Über die Giftstoffe des Knollenblätterpilzes. IV. Liebigs Ann Chem. 1938;533:93-117.

8. Wieland T, Miura T, Seeliger A. Analogs of phalloidin: D-Abu² ${ }^{2}$ Lys $^{7}$-phalloin, an Factin binding analog, its rhodamine conjugate (RLP) a novel fluorescent F-actin-probe, and D-Ala ${ }^{2}$ Leu $^{7}$ phalloin, an inert peptide. Int J Pept Protein Res. 1983;21:3-10.

9. Wieland T, Dudensing C. Über die Giftstoffe des grünen Knollenblätterpilzes, XI. YAmanitin, eine weitere Giftkomponente. Liebigs Ann Chem. 1941;600:156-60.

10. Diaz JH. Evolving global epidemiology, syndromic classification, general management, and prevention of unknown mushroom poisonings. Crit Care Med. 2005;33:419-26.

11. Hallen HE, Luo H, Scott Craig JS, Walton JD. Gene family encoding the major toxins of lethal Amanita mushrooms. Proc Natl Acad Sci U S A. 2007;104:19097-101.

12. Sgambelluri RM, Smith MO, Walton JD. Versatility of prolyl oligopeptidase B in peptide macrocyclization. ACS Synth Biol. 2018;7:145-52.

13. Luo H, Hong SY, Sgambelluri RM, Angelos E, Li X, Walton JD. Peptide macrocyclization catalyzed by a prolyl oligopeptidase involved in a-amanitin biosynthesis. Chem Biol. 2014;21:1610-7.

14. Luo H, Cai Q, Luli Y, Li X, Sinha R, Hallen-Adams HE, et al. The MSDIN family in amanitinproducing mushrooms and evolution of the prolyl oligopeptidase genes. IMA Fungus. 2018;9:225-42.

15. Pulman JA, Childs KL, Sgambelluri RM, Walton JD. Expansion and diversification of the MSDIN family of cyclic peptide genes in the poisonous agarics Amanita phalloides and A. bisporigera. BMC Genomics. 2016;17:1038.

16. Xue JH, Wu P, Chi YL, Xu LX, Wei XY. Cyclopeptides from Amanita exitialis. Nat Prod Bioprospect. 2011;1:52-6.

17. Clarke DB, Lloyd AS, Robb P. Application of liquid chromatography coupled to time-of-flight mass spectrometry separation for rapid assessment of toxins in Amanita mushrooms. Anal Methods. 2012;4:1298-309.

18. Pehk T, Haga M, Vija H, Lippmaa E. High-field 2D NMR spectroscopy of amanitin isomers. Magn Reson Chem. 1989;27:173-83.

19. Garcia J, Oliveira A, de Pinho PG, Freitas V, Carvalho A, Baptista P, et al. Determination of amatoxins and phallotoxins in Amanita phalloides mushrooms from northeastern Portugal by HPLC- DADMS. Mycologia. 2015;107:679-87.

20. Deng WQ, Li TH, Xi PG, Gan LX, Xiao ZD, Jiang ZD. Peptide toxin components of Amanita exitialis basidiocarps. Mycologia. 2011;103:946-9.

21. Tang SS, Zhou Q, He ZM, Luo T, Zhang P, Cai Q, et al. Cyclopeptide toxins of lethal amanitas: compositions, distribution and phylogenetic implication. Toxicon. 2016;120:78-88.

22. Letschert K, Faulstich H, Keller D, Keppler D. Molecular characterization and inhibition of amanitin uptake into human hepatocytes. Toxicol Sci. 2006;91:140-9.

23. Meier-Abt F, Faulstich H, Hagenbuch B. Identification of phalloidin uptake systems of rat and human liver. Biochim Biophys Acta. 2004;1664:64-9.

24. Azzolin L, Antolini N, Calderan A, Ruzza P, Sciacovelli M, Marin O, et al. Antamanide, a derivative of Amanita phalloides, is a novel inhibitor of the mitochondrial permeability transition pore. PLoS One. 2011;28:e16280.

25. Siemion IZ, Pedyczak A, Trojnar J, Zimecki M, Wieczorek Z. Immunosuppressive activity of antamanide and some of its analogues. Peptides. 1992;13:1233-7.

26. Thell K, Hellinger R, Schabbauer G, Gruber CW. Immunosuppressive peptides and their therapeutic applications. Drug Discov Today. 2014;19:645-53.

27. Wieczorek Z, Siemion IZ, Zimecki M, Bolewskapedyczak E, Wieland T. Immunosuppressive activity in the series of cycloamanide peptides from mushrooms. Peptides. 1993;14:1-5. 
28. Arnison PG, Bibb MJ, Bierbaum G, Bowers AA, Bugni TS, Bulaj G, et al. Ribosomally synthesized and post-translationally modified peptide natural products: overview and recommendations for a universal nomenclature. Nat Prod Rep. 2013;30:108-60.

29. Kume K, Ikeda M, Miura S, Ito K, Sato KA, Ohmori Y, et al. a-Amanitin restrains cancer relapse from drugtolerant cell subpopulations via TAF15. Sci Rep. 2016;6:25895.

30. Liu Y, Zhang X, Han C, Wan G, Huang X, Ivan C, et al. TP53 loss creates therapeutic vulnerability in colorectal cancer. Nature. 2015;520:697-701.

31. Moldenhauer G, Salnikov AV, Luttgau S, Herr I, Anderl J, Faulstich H. Therapeutic potential of amanitin-conjugated anti-epithelial cell adhesion molecule monoclonal antibody against pancreatic carcinoma. J Natl Cancer Inst. 2012;104:622-34.

32. Craig EW, Avasthi P. Visualizing filamentous actin using phalloidin in Chlamydomonas reinhardtii. Bio Protoc. $2019 ; 9: \mathrm{e} 274$.

33. Raymond G, Potreau D, Cognard C, Jahn W, Wieland T. Antamanide antagonizes the phalloidininduced negative inotropic effect and blocks voltage dependently the fast outward $\mathrm{K}^{+}$current in voltagclamped frog muscle fibres. Eur J Pharmacol. 1987;138:21-7.

34. Luo H, DuBois B, Sgambelluri RM, Angelos ER, Li X, Holmes D, et al. Production of ${ }^{15} \mathrm{~N}$-labeled aamanitin in Galerina marginata. Toxicon. 2015;103:60-4.

35. Pringle A, Adams RI, Cross HB, Bruns TD. The ectomycorrhizal fungus Amanita phalloideswas introduced and is expanding its range on the west coast of North America. Mol Ecol. 2009;18:817-33.

36. Li P, Deng WQ, Li TH. The molecular diversity of toxin gene families in lethal Amanita mushrooms. Toxicon. 2014;83:59-68.

37. Li P, Deng WQ, Li TH, Song B, Shen YH. Illumina-based de novo transcriptome sequencing and analysis of Amanita exitialis basidiocarps. Gene. 2013;532:63-71.

38. Kim D, Langmead B, Salzberg SL. HISAT: a fast spliced aligner with low memory requirements. Nat Methods. 2015;12:357-60.

39. Pertea M, Pertea GM, Antonescu CM, Chang TC, Mendell JT, Salzberg SL. StringTie enables improved reconstruction of a transcriptome from RNA-seq reads. Nat Biotechnol. 2015;33:290-5.

40. Luo H, Hallen-Adams HE, Scott-Craig JS, Walton JD. Colocalization of amanitin and a candidate toxinprocessing prolyl oligopeptidase in Amanita basidiocarps. Eukaryot Cell. 2010;9:1891-900.

41. Luo H, Hallen-Adams HE, Scott-Craig JS, Walton JD. Ribosomal biosynthesis of aamanitin in Galerina marginata. Fungal Genet Biol. 2012;49:123-9.

42. May JP, Perrin DM. Tryptathionine bridges in peptide synthesis. Biopolymers. 2007;88:714-24.

43. Kim S, Pevzner PA. MS-GF+ makes progress towards a universal database search tool for proteomics. Nat Commun. 2014;5:5277.

44. Yang H, Chi H, Zhou WJ, Zeng WF, He K, Liu C, et al. Open-pNovo: de novo peptide sequencing with thousands of protein modifications. J Proteome Res. 2017;16:645-54.

45. Tautenhahn R, Patti GJ, Rinehart D, Siuzdak G. XCMS Online: a webbased platform to process untargeted metabolomic data. Anal Chem. 2012;84:5035-9.

\section{Supplementary Files Legend}

Supplementary information accompanies this paper at https:

Additional file 1: Figure S1. The monoisotopic masses of candidate new cyclic peptides in Amanita rimosa. Figure S2. The monoisotopic masses of candidate new cyclic peptides in Amanita pallidorosea. Figure S3. The monoisotopic masses of candidate new cyclic peptide in Amanita exitialis. Figure S4. Tandem mass spectrometry of novel cyclic peptides in Amanita rimosa. Figure S5. Tandem mass spectrometry of novel cyclic peptides in Amanita pallidorosea. Figure S6. Tandem mass spectrometry of novel cyclic peptides in Amanita exitialis. Figure S7. Mass spectrometry of amanexitide from Amanita exitialis. Table S1. MSDIN family and novel cyclic peptides in Amanita pallidorosea.

\section{Figures}



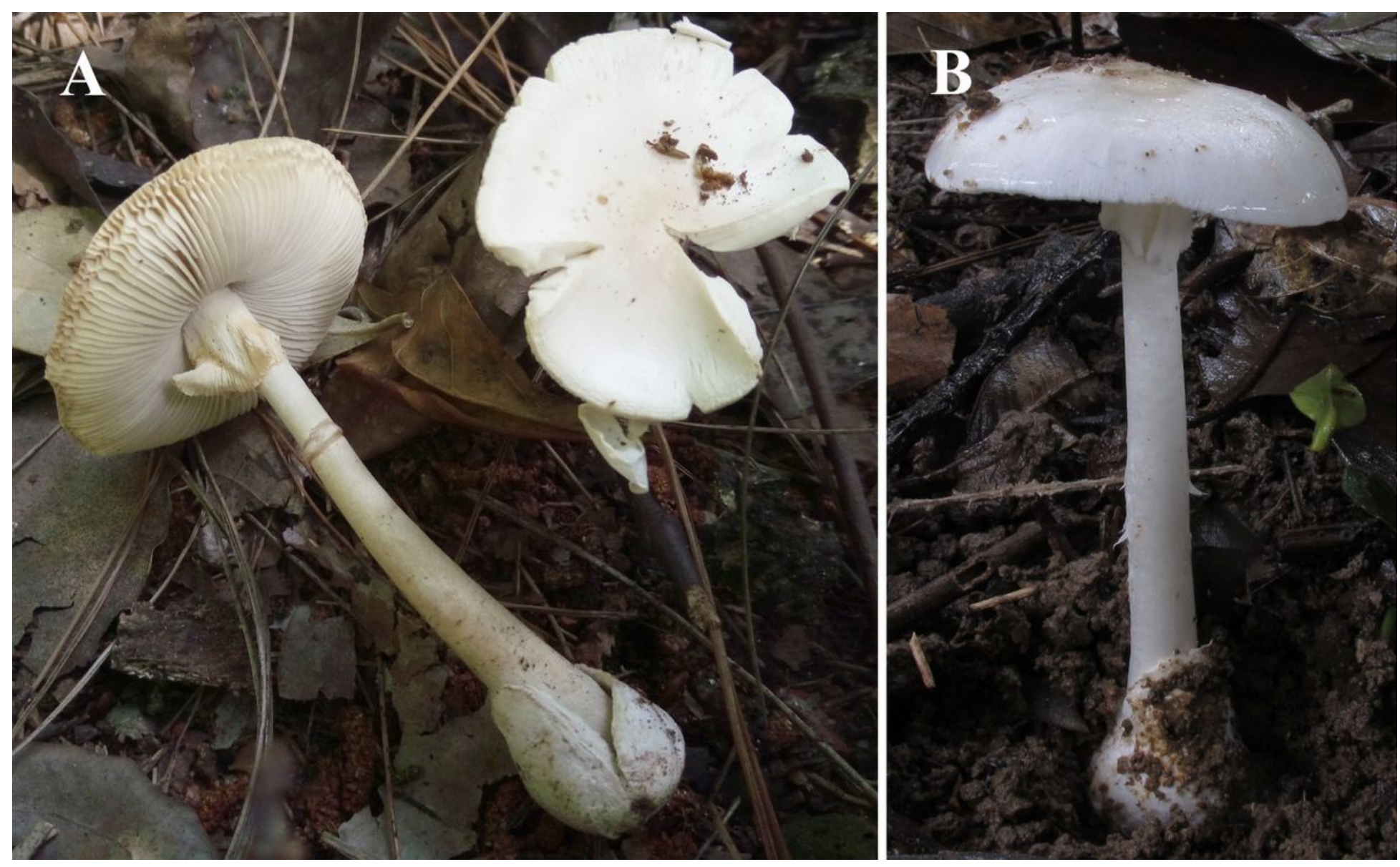

Figure 1

Deadly Amanita species for genome sequencing and peptide analyses. (A) A. rimosa; (B) A. exitialis. 


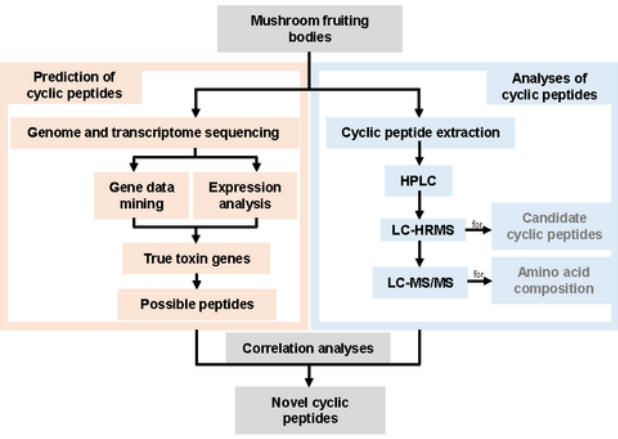

Figure 2

A flowchart for characterizing cyclic peptides in Amanita species. 

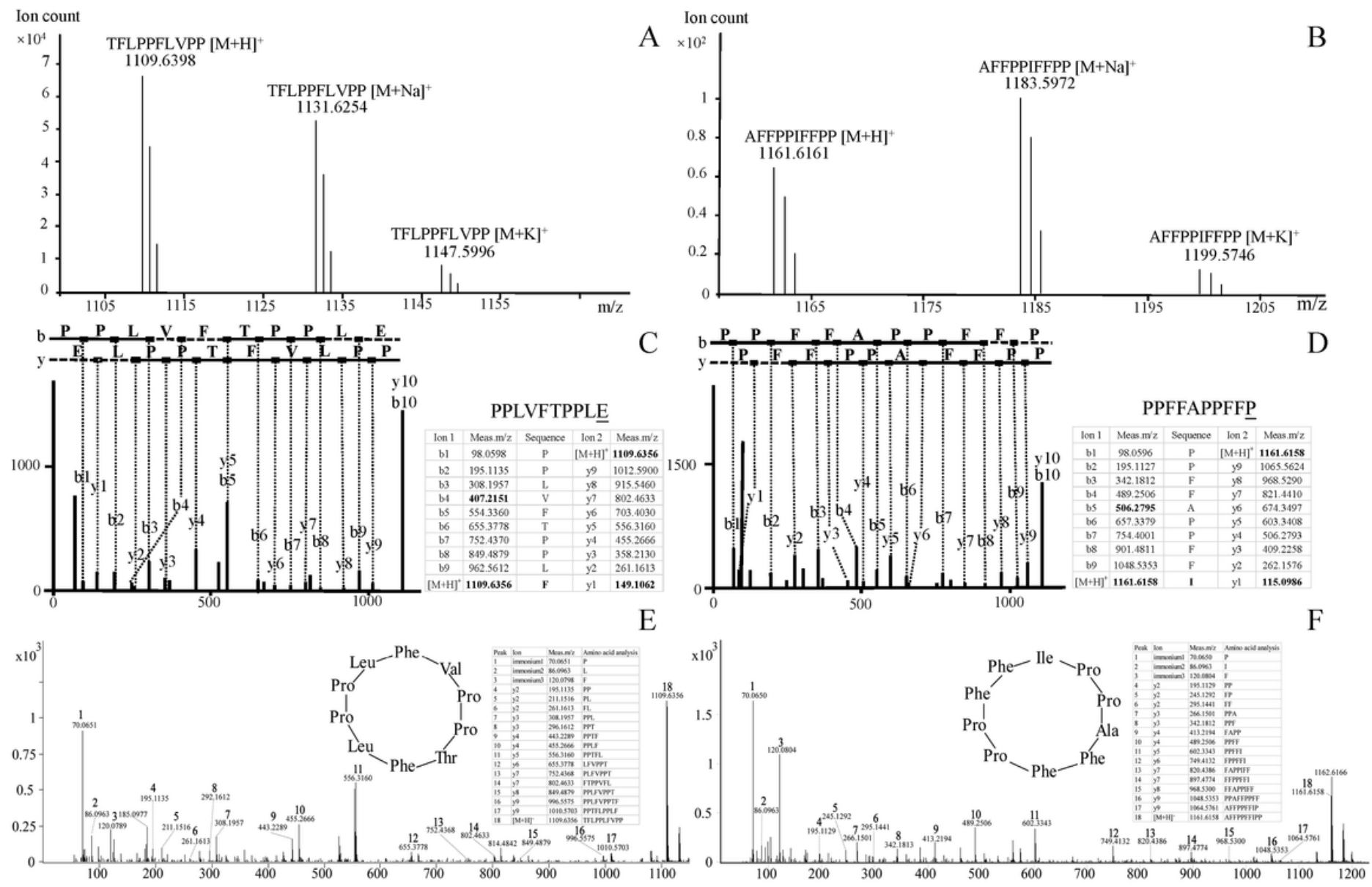

Figure 3

LC-HRMS and the amino acid composition of CyIG1 and CyIG2 in Amanita subjunquillea. Positive LC-HRMS spectra of CyIG1 (A) and CylG2 (B), with $[\mathrm{M}+\mathrm{Na}]+$ and $[\mathrm{M}+\mathrm{K}]+$ adduct ions indicated. (C) and (D) Amino acid composition analysis through CCMS for CylG1 and CyIG2, with b- and y-type fragment ions shown (bold fonts are manual fillings for ions not recognized by the website); predicted linear peptide sequences were shown above the inserted tables (the last amino acids were underlined as they were erroneous). (E) and (F) Manual analyses of recognized fragment ions for CyIG1 and CyIG2 with inserted tables of matched amino acids; immonium ions were shown when present. The determined cyclic peptides were shown as circles. 


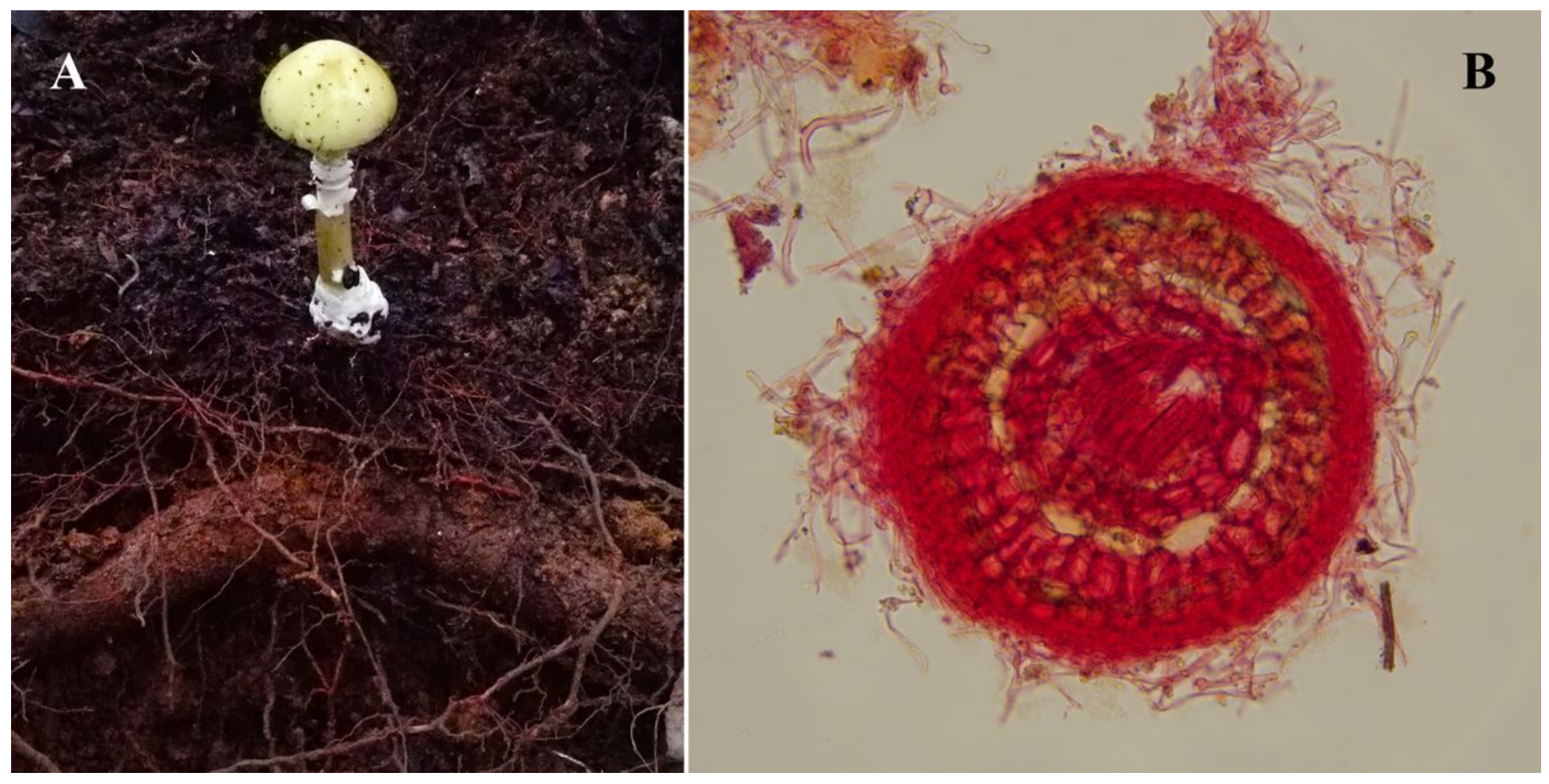

\section{Figure 4}

Mycorrhiza of Amanita subjunquillea. (A) A fruiting body of A. subjunquillea and the connected plant roots. (B) A cross section of a root tip associated with $A$. subjunquillea (Hartig net distinguishable). 

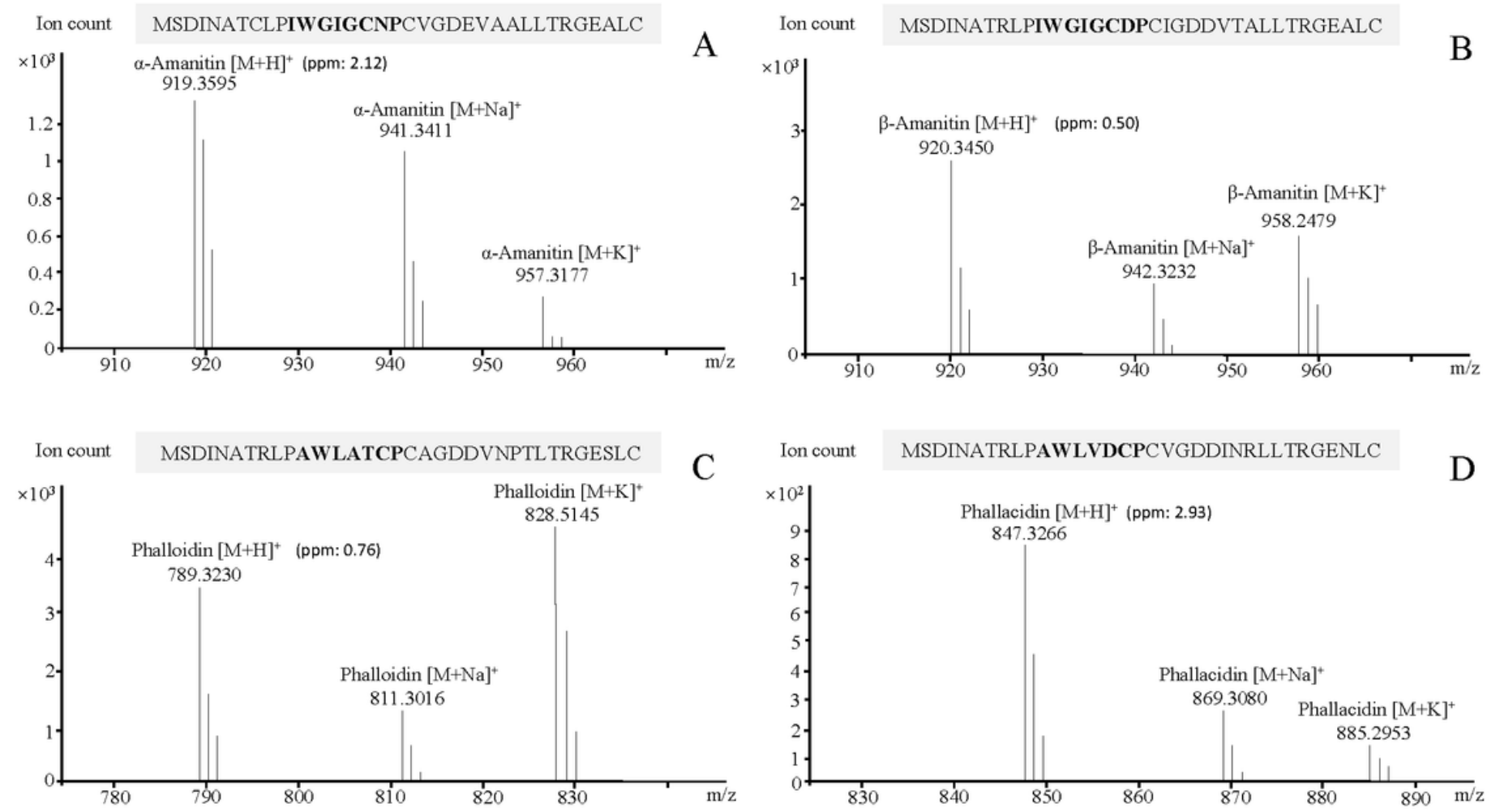

\section{Figure 5}

Cyclic peptide toxins discovered in the mycorrhiza of Amanita subjunquillea. Three adduct ions of a-amanitin (A), $\beta$-amanitin (B), phalloidin (C) and phallacidin (D). The corresponding MSDIN genes cloned were listed (shaded) above each section.

\section{Supplementary Files}

This is a list of supplementary files associated with this preprint. Click to download.

- Additionalfile1202001133.docx 